\title{
Outcomes of salvage total hip arthroplasty after failed osteosynthesis for collum femoris fractures
}

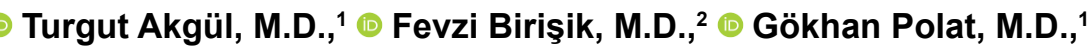 \\ (1) Cengiz Şen, M.D., ${ }^{1}$ 을 Önder İsmet Kılıçoğlu, M.D. ${ }^{1}$
}

\begin{abstract}
1'Department of Orthopedics and Traumatology, İstanbul University İstanbul Faculty of Medicine, İstanbul-Turkey ${ }^{2}$ Department of Orthopedics and Traumatology, İstanbul Training and Research Hospital, İstanbul-Turkey
\end{abstract}

\begin{abstract}
BACKGROUND: This study is an investigation of the outcomes of salvage total hip arthroplasty (THA) to treat collum femoris fractures that resulted in complications or failure after osteosynthesis.

METHODS: Twenty patients ( 6 male, I 4 female; mean age: 56.7 years) who underwent salvage total hip arthroplasty (THA) between 1988 and 2012 due to failure developing after closed reposition and osteosynthesis in the treatment of collum femoris fractures were included in the study. The type of osteosynthesis, and the length of time until failure and before THA application after collum femoris fracture were recorded. Cementless acetabular and femoral components were used in all of the patients. Complications were defined as those occurring during and after surgery. The clinical results were assessed with the Harris Hip Score (HHS) and the presence of loosening was assessed with radiological evaluation in follow-up.
\end{abstract}

RESULTS: The mean length of the follow-up period was 59.4 months (range: 15-178 months). The collum femoris fractures of the 20 patients were classified as: 5 Garden type II, I 3 type III, 2 type IV, and 3 Pauwels type I, 8 type II, and 9 type III. Cannulated screws were used in 13 patients (65\%) and dynamic hip screw (DHS) fixation was used in 7 patients (35\%). Complications observed after osteosynthesis were nonunion in 4 cases (20\%), malunion in $2(10 \%)$, avascular necrosis in $10(50 \%)$, and implant failure in $4(20 \%)$. A mean of 9.66 months (range: 3-54 months) elapsed before osteosynthesis failure and the mean length of time until THA was 3 I.6 \pm 5 I.7 months. There was no statistically significant difference between cannulated screw and DHS fixation in the development of complications $(p=0.084)$. Early dislocation $(5 \%)$, periprosthetic fracture $(5 \%)$ and acetabular protrusion $(5 \%)$ were recorded as complications. A revision was made upon determination of loosening in the 10th year in the patient who developed early dislocation. While the mean HHS was $54.05 \pm 8.22$ before THA, it was evaluated to be $86.45 \pm 8.73$ at the last follow-up, which was a statistically significant difference $(p<0.0001)$.

CONCLUSION: The study findings demonstrated that THA applied with suitable surgical technique is a safe and successful method that may be used after failed osteosynthesis in cases of collum femoris fracture.

Keywords: Hip arthroplasty; hip fracture; osteosynthesis.

\section{INTRODUCTION}

Osteosynthesis is recommended as the first treatment of choice in the early period of collum femoris fracture treatment. There is some divergence of opinion about treatment options in patients of advanced age, especially in cases of displaced collum femoris fracture. ${ }^{[1-3]}$ Although some authors recommend total hip arthroplasty (THA), stating that there is high rate of failure after osteosynthesis, the traditionally accepted view is to use the osteosynthesis technique in patients over 65 years of age. ${ }^{[2]}$ Osteosynthesis treatment includes open and closed reposition surgical options in combination with cannulated screw or dynamic hip screw (DHS) application. Independent of the option, the failure rate of osteosyn-

Cite this article as: Akgül T, Birişik F, Polat G, Şen C, Kılıçoğlu Öİ. Outcomes of salvage total hip arthroplasty after failed osteosynthesis for collum femoris fractures. Ulus Travma Acil Cerrahi Derg 2019;25:287-292.

Address for correspondence: Turgut Akgül, M.D.

İstanbul Üniversitesi İstanbul Tıp fakültesi, Ortopedi ve Travmatoloji Anabilim Dalı, İstanbul, Turkey.

Tel: +90 212 - 4142000 E-mail: doktorturgut@yahoo.com

Ulus Travma Acil Cerrahi Derg 2019;25(3):287-292 DOI: 10.5505/tjtes.2018.55506 Submitted: 16.04.2018 Accepted: 06.09.2018 Online: I6.05.2019

Copyright 2019 Turkish Association of Trauma and Emergency Surgery 
thesis in advanced age is reported to be $22.6 \%{ }^{[4]}$ THA is a salvage therapy in the treatment of failure developing after osteosynthesis. There is no consensus in the literature about the success or complications of hip arthroplasty performed as salvage therapy. While some authors report poor clinical outcomes and high complication rates, others report successful clinical outcomes and low complication rates. ${ }^{[5,6]}$

This study was an evaluation of the clinical and radiological outcomes of THA applications performed as salvage therapy in the treatment of problems occurring related to osteosynthesis for collum femoris fractures.

\section{MATERIALS AND METHODS}

Twenty patients who underwent THA between 1988 and 2012 due to the development of failure after closed reposition and osteosynthesis following a collum femoris fracture were included in the study. Patients with union occurring after closed reposition but coxarthrosis developing in the late period were not included in the study. Nonunion, avascular necrosis, and implant failure were considered to be preoperative osteosynthesis failures. Femoral stem with cement procedures and hemiarthroplasty cases were excluded from the study. The mean age of the patients included in the study was $56.75 \pm 12$. 15 years. The collum femoris fractures were classified according to the Garden and Pauwels systems and the surgical implant was performed with cannulated screw or DHS fixation.

After removal of osteosynthesis materials in the lateral decubitus position with a lateral approach as the standard method, the anterior capsule and labrum were partially resected to achieve standard exposure. The acetabular component was press fit and an acetabular screw was added for extra stability. The femoral component was press fit without cement. A highly cross-linked polyethylene acetabular insert was used in the last 14 cases that were operated on after 2006. A 28$\mathrm{mm}$ metal cobalt chrome femoral head was used in all of the patients. Patients with a cemented femoral component were excluded from this study to create a homogenous series.

The length of time between the fracture and osteosynthesis as well as between the osteosynthesis and the application of salvage THA was recorded. The presence of $>3 \mathrm{~mm}$ or $>2^{\circ}$ change in position of the femoral component observed on $X$-ray, or the presence of $>2^{\circ}$ or $\geq 2 \mathrm{~mm}$ change in position of the acetabular component and presence of pain were considered to indicate loosening. ${ }^{[7]}$

Enoxaparin was administered at a dose of 0.4 cc subcutaneously as prophylaxis for deep-vein thrombosis and the patients were discharged with directions for the use of $300 \mathrm{mg}$ oral acetylsalicylic acid. The use of a cephalosporin antibiotic initiated for prophylaxis before surgery was maintained for 48 hours and then discontinued.
The patients were allowed to walk with tolerated weightbearing within 48 hours after the surgery. Full weight-bearing was initiated at 6 weeks after surgery. The HHS was used in the clinical assessment of the patients. Complications that developed after surgery and their treatments were determined. IBM SPSS Statistics for Windows, Version 20.0 (IBM Corp., Armonk, NY, USA) was used to perform the statistical analysis. A t-test was used for intergroup comparisons of quantitative data and a chi-square test for intergroup comparisons of qualitative data. Post-hoc power analysis was performed by using G*power version 3.I.7 (Faul, F. et al., Heinrich-HeineUniversität Düsseldorf, Düsseldorf, Germany). The comparison of preoperative and postoperative HHS values had a level of $\alpha=0.05$, power $100 \%(1-\beta=1.00)$, and impact magnitude (d) of 6.50 (cannulated screw) and 3.69 (DHS).

\section{RESULTS}

Twenty hips of 6 male and 14 female patients were included in the study. The development of a complication after osteosynthesis occurred at a mean of 9.66 months (range: 3-54 months) and THA was performed at a mean $31.6 \pm 51.7$ months (range: 5-240 months) after osteosynthesis surgery (Table I).

The mean duration of the follow-up period of the patients included in the study was 59.4 \pm 52.4 months (range: 15-178 months). Five patients were classified as type II, I 3 patients as type III, and 2 patients as type IV according to the Garden classification system, and 3 patients were considered to be type I, 8 patients type II, and 9 patients type III according to the Pauwel classification system. The mechanism of the fracture was a simple fall for II patients, 7 patients had a fall from a height, and 2 patients were involved in traffic accidents. Osteosynthesis applied due to a collum femoris fracture was performed on a traction table using 3 cannulated screws in 13 patients (65\%) (Fig. Ia, b) and DHS in 7 patients (35\%) after closed reposition. Complications developing after osteosynthesis were nonunion in 4 patients, malunion in 2 patients, symptomatic avascular necrosis in 10 patients, and implant failure in 4 patients (Table I).

Femoral components used for THA as prosthesis options were inserted into the femur without cement (Fig. Ic). An acetabular component with screw fixation was used in 18 of the patients and a porous-coated acetabular component without screw fixation was used in 2 patients. The diameter of the implants inserted into the acetabulum was between 46 and $54 \mathrm{~mm}$. Anterolateral entry was used in all patients, with a standard lateral approach.

Due to excessive reaming in I patient during preparation of a line-to-line presplit of the acetabular component, the medial acetabular wall was breached. It was not possible to press fit the acetabular component or to use only cement. This problem was resolved with an acetabular reconstruction cage and an acetabular liner with cement. Dislocation was seen in I 


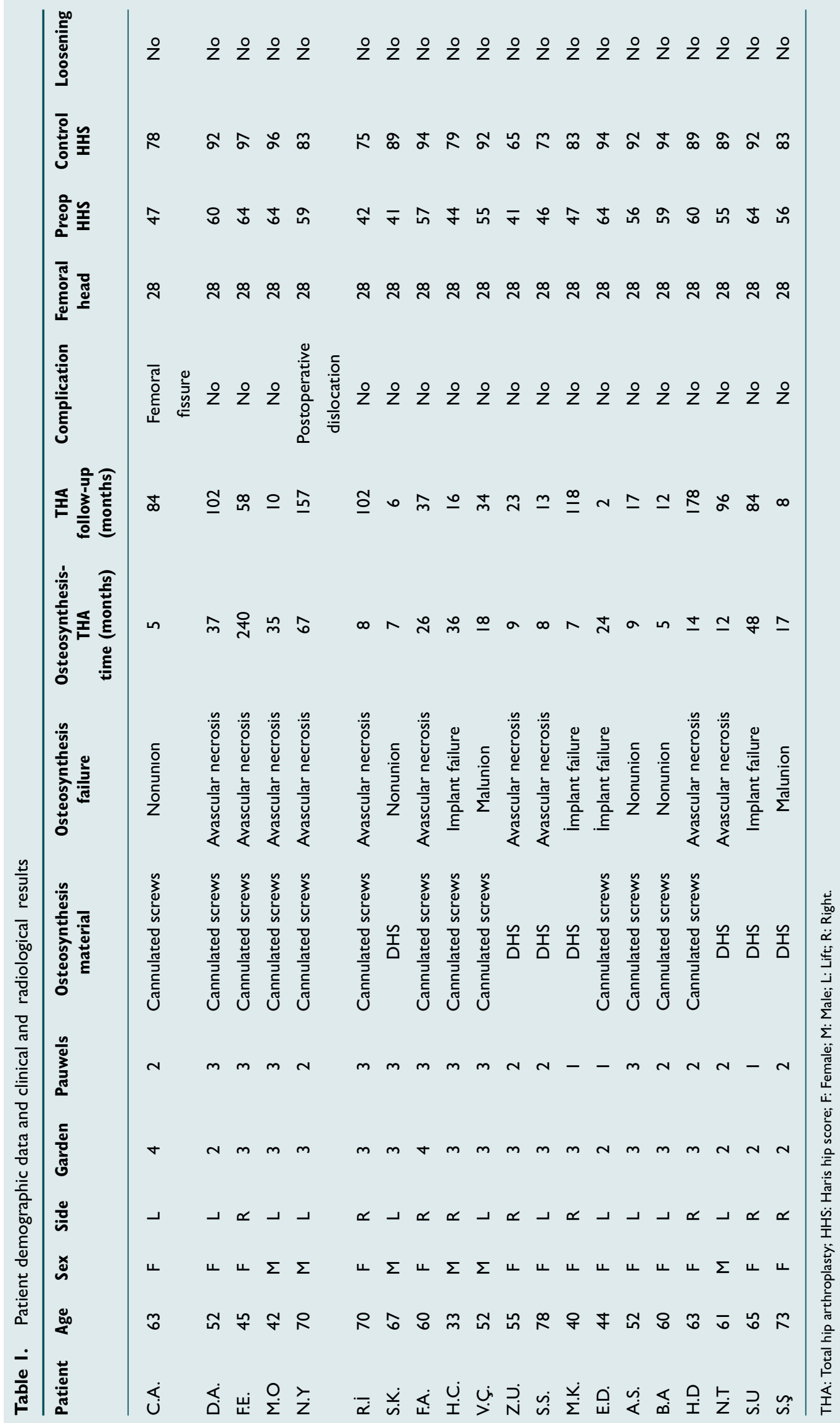



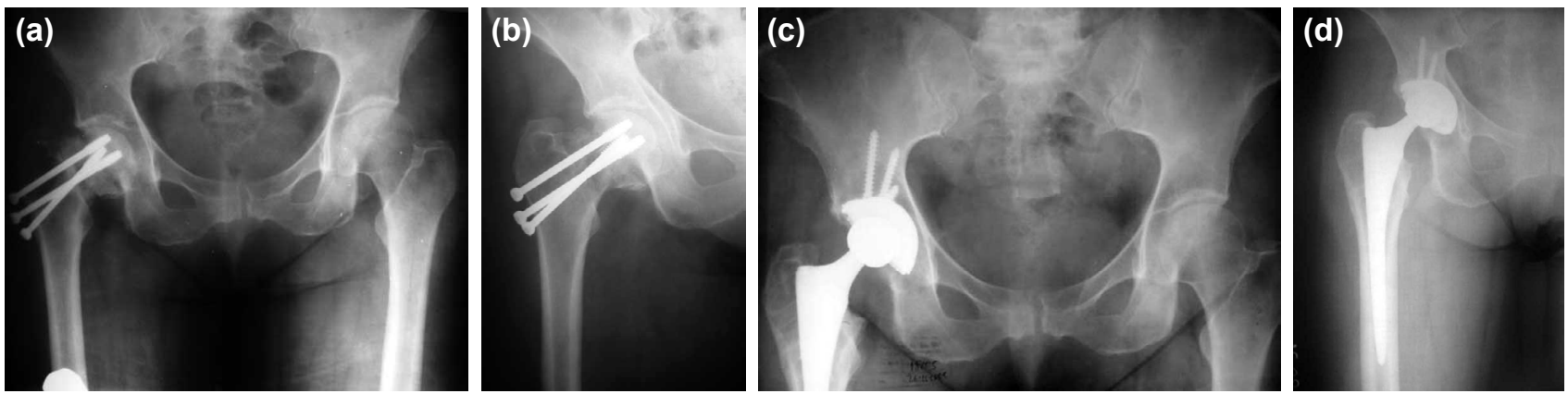

Figure 1. (a) A63-year-old female referred for pain in the right hip. (a) Preoperative pelvis anteroposterior (AP) and (b) hip AP X-ray revealing failed osteosynthesis with cannulated screws. (c) Early postoperative X-ray. (d) Control X-ray demonstrating enough union.

patient in the early period and treated with open reduction and femoral component revision. The femoral component was malpositioned and the abductor tension was loose. The position of the femoral component was adjusted with a lateralized component. Debridement was performed and a second surgery was performed for this patient due to a superficial surgical site infection in the early period. Loosening of the arthroplasty was encountered at the $10^{\text {th }}$ year follow-up of the patient. Deep infection was not encountered in any of the patients. Due to the occurrence of a nondisplaced fracture during the insertion of the femoral component in I patient during the surgery, osteosynthesis was provided with a surgical cable.

Final follow-up radiological evaluations were conducted in all but 2 cases; the patients had died due to diseases not related to the THA surgery (Fig. Id). Those 2 patients had 84 months and 8 months of radiological follow-up. Revision was performed in I patient (5\%) after loosening. Radiological loosening and corrosion of polyethylene components was not observed in any of the other patients.

The mean HHS assessment performed in the clinical evaluation of the patients before the salvage THA was $54.05 \pm 8.22$, and the mean value recorded in the last follow-up visit was $86.45 \pm 8.73$, which demonstrated a statistically significant difference $(p<0.0001)$.

\section{DISCUSSION}

Ordinarily, the first treatment of choice in a collum femoris fracture is osteosynthesis. ${ }^{[1,8]}$ In a meta-analysis regarding displaced collum femoris fractures, the failure rate of correction within the first 2 years was reported to be $26 \%$ to $30 \%$. ${ }^{[9]}$ Parker et al. ${ }^{[10]}$ reported that the failure rate in cases of osteosynthesis was high and secondary surgeries were required. Failure can be treated with the application of salvage THA. [5, II] Some authors suggest performing THA in the first instance due to the failure rate of osteosynthesis, especially in patients over 70 years of age with a displaced collum femoris fracture. ${ }^{[1]}$

McKinley et al..$^{[5]}$ compared the results of THA performed in the early period after a collum femoris fracture and the results of THA performed as salvage treatment, and they reported higher complication rates and a low survival rate in the patients who underwent a salvage procedure after an opere collum femoris fracture. In a comparative study performed by Oztürkmen et al., ${ }^{[12]}$ the authors found a higher rate of failure in salvage THA cases compared with primary THA cases. The authors reported a higher complication rate with salvage THA after failure of osteosynthesis performed following proximal femur fractures, but the cases with a collum femoris fracture were not evaluated separately. ${ }^{[1,14]}$

Archibeck et al. ${ }^{[5]}$ reported that THA used to treat failure after osteosynthesis for a collum femoris fracture had a successful and acceptable complication rate. Mortazavi et al. ${ }^{[16]}$ found that among THA cases, collum femoris fractures had a more successful course with a lower complication rate compared with intertrochanteric fractures. However, both successful and unsuccessful results have been published in the literature. ${ }^{[5,6]}$ Said et al. ${ }^{[17]}$ reported a study which included eight patients with salvage THA. In this study, six patients had achieved good functional outcome and pain-free gait and the other two patients had unsatisfactory result. Archibeck et al. ${ }^{[15]}$ reported a mean HHS of 82 at the last follow-up in salvage THA cases. The mean HHS was determined to be $86.45 \pm 8.73$ in the follow-up of the cases included in our study. The clinical success rate in our study was higher than that of similar studies. A complication rate of $15 \%$ was determined in the present study. Mortazavi et al., ${ }^{[16]}$ Archibeck et al., ${ }^{[15]}$ Mehlhoff et al., ${ }^{[18]}$ McKinley et al., ${ }^{[5]}$ and Oztürkmen et al. ${ }^{[12]}$ reported complications related to orthopedics at a rate of $10 \%, 12 \%, 15 \%, 18 \%$, and $60 \%$, respectively.

Complications that may develop after salvage THA include early dislocation, periprosthetic fracture, and infection developing during surgery. The rate reported for early dislocation in the literature ranges between $0 \%$ and $20 \%$. While McKinley et al. ${ }^{[5]}$ and Oztürkmen et al. ${ }^{[12]}$ reported early dislocation at a rate of $20 \%$, Mortazavi et al., ${ }^{[16]}$ Lombardi et al. ${ }^{[19]}$ and Mehlhoff et al. ${ }^{[18]}$ reported early dislocation at a rate of $0 \%$ with salvage THA performed after collum femoris fracture. In the study performed by Mortazavi et al., ${ }^{[16]}$ they found that most of the dislocation cases in the literature were cases of 
surgery with the posterolateral incision technique and this could be a risk factor for early dislocation. A lateral approach was used in our study, and we observed early dislocation at a rate of $5 \%$, which was less than the rate reported in much of the literature.

The rate of infection developing in salvage THA performed after collum femoris fracture is between $1.2 \%$ and $12 \%$ in the literature. ${ }^{[12,14-16]}$ In our study, no instance of prosthesis infection in the early or late period was encountered. The rate of infection developing after primary salvage THA performed following collum femoris fracture has been reported to be $2.9 \%{ }^{[12]}$

Furthermore, there was no case of periprosthetic fracture impairing the stability of the prosthesis. The subtrochanteric region was passed over sufficiently with the primary prosthesis and cannulated screw and short DHS fixation were used. In I patient (5\%), nondisplaced fracture developed at the upper level of the screw entrance while a larger size prosthesis measured during surgery with a template was being placed but uneventful improvement was seen after fixation with a cable. Fractures developing during surgery occur generally at the level of implant entry in the lateral cortex in cases of arthroplasty performed after peritrochanteric fracture. Protective cable application is recommended to prevent fractures occurring during surgery. ${ }^{[15]}$ While DeHaan et al. ${ }^{[14]}$ determined a risk for periprosthetic fracture of $9 \%$, the rate has been reported to be $2.5 \%$ in the application of salvage THA after a collum femoris fracture. Oztürkmen et al. ${ }^{[12]}$ reported a higher rate of $14.7 \%$, while Archibeck et al. ${ }^{[5]}$ found a rate of $4 \%$.

There are not enough data in the literature to adequately define a high complication rate after salvage THA for a failed proximal femoris fracture. Franzén et al. ${ }^{[20]}$ noted greater risk in patients over 70 years of age, but noted that the complication rate was similar to that of primary THA for treatment of a collum femoris fracture. Recently, Tetsunaga et al. ${ }^{[21]}$ presented their research comparing the results of THA after failed pertrochanteric and collum femoris fractures, and they observed that THA after a failed collum femoris fracture had a lower complication rate. Abductor muscle insufficiency, trochanteric malunion, and the lack of restoration of vertical and lateral offset associated with dislocation are potential reasons for complications after salvage hip arthroplasty. ${ }^{[15,18-21]}$

Weaknesses of our study are the retrospective design and small sample size. A different feature of our study from others is that the mean age is $>65$ years in the literature, while the mean age of the patients in our group was 57 years.

While osteosynthesis is the first treatment of choice after a collum femoris fracture, arthroplasty options are current methods of treatment in the event of failure. In our study, we obtained highly successful clinical results after cementless THA performed after collum femoris fractures with a low complication rate. THA performed with a suitable surgical technique is a safe and successful method of treatment after failed osteosynthesis in cases of a collum femoris fracture.

Conflict of interest: None declared.

\section{REFERENCES}

1. Palm H, Krasheninnikoff M, Holck K, Lemser T, Foss NB, Jacobsen S, et al. A new algorithm for hip fracture surgery. Reoperation rate reduced from $18 \%$ to $12 \%$ in 2,000 consecutive patients followed for 1 year. Acta Orthop 2012;83:26-30.

2. Raaymakers EL. Fractures of the femoral neck: a review and personal statement. Acta Chir Orthop Traumatol Cech 2006;73:45-59.

3. Knobe M, Siebert CH. Hip fractures in the elderly: Osteosynthesis versus joint replacement. [Article in German]. Orthopade 2014;43:314-24.

4. Gjertsen JE, Vinje T, Engesaeter LB, Lie SA, Havelin LI, Furnes O, et al. Internal screw fixation compared with bipolar hemiarthroplasty for treatment of displaced femoral neck fractures in elderly patients. J Bone Joint Surg Am 2010;92:619-28.

5. McKinley JC, Robinson CM. Treatment of displaced intracapsular hip fractures with total hip arthroplasty: comparison of primary arthroplasty with early salvage arthroplasty after failed internal fixation. J Bone Joint Surg Am 2002;84-A:2010-5.

6. Hammad A, Abdel-Aal A, Said HG, Bakr H. Total hip arthroplasty following failure of dynamic hip screw fixation of fractures of the proximal femur. Acta Orthop Belg 2008;74:788-92.

7. Martell JM, Pierson RH 3rd, Jacobs JJ, Rosenberg AG, Maley M, Galante JO. Primary total hip reconstruction with a titanium fiber-coated prosthesis inserted without cement. J Bone Joint Surg Am 1993;75:554-71.

8. Nikolopoulos KE, Papadakis SA, Kateros KT, Themistocleous GS, Vlamis JA, Papagelopoulos PJ, et al. Long-term outcome of patients with avascular necrosis, after internal fixation of femoral neck fractures. Injury 2003;34:525-8.

9. Lu-Yao GL, Keller RB, Littenberg B, Wennberg JE. Outcomes after displaced fractures of the femoral neck. A meta-analysis of one hundred and six published reports. J Bone Joint Surg Am 1994;76:15-25.

10. Parker MJ, Gurusamy K. Internal fixation versus arthroplasty for intracapsular proximal femoral fractures in adults. Cochrane Database Syst Rev 2006;(4):CD001708.

11. Tabsh I, Waddell JP, Morton J. Total hip arthroplasty for complications of proximal femoral fractures. J Orthop Trauma 1997;11:166-9.

12. Oztürkmen Y, Karamehmetoğlu M, Azboy I, Açikgöz I, Caniklioğlu M. Comparison of primary arthroplasty with early salvage arthroplasty after failed internal fixation for displaced femoral neck fractures in elderly patients. [Article in Turkish]. Acta Orthop Traumatol Turc 2006;40:291300 .

13. Srivastav S, Mittal V, Agarwal S. Total hip arthroplasty following failed fixation of proximal hip fractures. Indian J Orthop 2008;42:279-86.

14. DeHaan AM, Groat T, Priddy M, Ellis TJ, Duwelius PJ, Friess DM, et al. Salvage hip arthroplasty after failed fixation of proximal femur fractures. J Arthroplasty 2013;28:855-9.

15. Archibeck MJ, Carothers JT, Tripuraneni KR, White RE Jr. Total hip arthroplasty after failed internal fixation of proximal femoral fractures. J Arthroplasty 2013;28:168-71.

16. Mortazavi SM, R Greenky M, Bican O, Kane P, Parvizi J, Hozack WJ. Total hip arthroplasty after prior surgical treatment of hip fracture is it 
always challenging? J Arthroplasty 2012;27:31-6.

17. Said GZ, Farouk O, El-Sayed A, Said HG. Salvage of failed dynamic hip screw fixation of intertrochanteric fractures. Injury 2006;37:194-202.

18. Mehlhoff T, Landon GC, Tullos HS. Total hip arthroplasty following failed internal fixation of hip fractures. Clin Orthop Relat Res 1991;(269):32-7.

19. Lombardi AV Jr, Skeels MD, Berend KR. Total hip arthroplasty after failed hip fractures: a challenging act. Orthopedics 2007;30:752-3.

20. Franzén H, Nilsson LT, Strömqvist B, Johnsson R, Herrlin K. Secondary total hip replacement after fractures of the femoral neck. J Bone Joint Surg Br 1990;72:784-7.

21. Tetsunaga T, Fujiwara K, Endo H, Noda T, Tetsunaga T, Sato T, et al. Total hip arthroplasty after failed treatment of proximal femur fracture. Arch Orthop Trauma Surg 2017;137:417-24.

\section{ORIJINAL ÇALIŞMA - ÖZET}

\section{Femur boyun kırıklarında osteosentez sonrası gelişen komplikasyonların tedavisinde total kalça protezi uygulamalarının sonuçları \\ Dr. Turgut Akgül, ${ }^{1}$ Dr. Fevzi Birişik, ${ }^{2}$ Dr. Gökhan Polat, ${ }^{1}$ Dr. Cengiz Şen, ${ }^{1}$ Dr. Önder İsmet Kılıçoğlu ${ }^{1}$}

\section{${ }^{1}$ İstanbul Üniversitesi İstanbul Tıp fakültesi, Ortopedi ve Travmatoloji Anabilim Dalı, İstanbul}

${ }^{2}$ İstanbul Eğitim ve Araştırma Hastanesi, Ortopedi ve Travmatoloji Kliniği, İstanbul

AMAÇ: Bu çalışmada osteosentez sonrası komplikasyon gelişmiş veya başarısız olunmuş kollum femoris kırıklarının, kurtarıcı total kalça artroplastisi (TKA) ile tedavisinin sonuçları araştııılı.

GEREÇ VE YÖNTEM: 1988 ile 2012 yılları arası kollum femoris kııı̆ı tedavisinde kapalı repozisyon ve osteosentez sonrası başarısızlık gelişen ve kurtarıcı TKA yapılan 20 hasta (6 erkek, 14 kadın; ortalama yaş: 56.7) çalışmaya alındı. Kollum femoris kırıkları sonrası osteosentez şekli, başarısızık gelişme süresi ve TKA uygulama süreleri kaydedildi. Hastalara sementsiz femoral ve asetabuler komponent kullanıldı. Komplikasyonlar operasyon esnası ve sonrası olarak belirlendi. Son kontrolde Haris kalça skorlaması ile klinik sonuçlar ve çekilen grafiler ile gevşeme varlığı değerlendirildi.

BULGULAR: Hastaların takip süreleri ortalama 59.4 (dağıım, 15-178) ay idi. TKA uygulanan 20 hastanın kollum femoris kırıklarının sınıflaması osteosentez sonrasında komplikasyonlar kaynamama 4 (\%25), malunion 2 (\%।0), avasküler nekroz 9 (\%45), implant yetersizliği 4 (\%20) idi. Komplikasyonlar gelişmesinde kanüle vida ve DHS arasında istatistiksel anlamlı farklılık bulunmamakta idi $(p=0.084)$. Komplikasyon olarak erken dislokasyon (\%5), protez çevresi kırı (\%5) ve asetabuler protrüzyon (\%5) saptandı. Erken dislokasyon gelişen hastada 10. yılda gevşeme saptanması üzerine revizyon yapıldı. TKA öncesi HHS 54.05 iken son kontrolde 86.45 olarak değerlendirildi ve istatistiksel olarak aralarında anlamlı bir fark saptandı $(\mathrm{p}<0.000 \mathrm{I})$.

TARTIŞMA: Çalışma bulgularımız, kollum femoris kırıklarında başarısız osteosentez sonrası TKA uygun cerrahi teknik ile başarılı ve güvenli bir yöntem olduğunu göstermektedir.

Anahtar sözcükler: Femur boyun kırı̆̆ı; kalça protezi; osteosentez.

Ulus Travma Acil Cerrahi Derg 2019;25(3):287-292 doi: 10.5505/tjtes.2018.55506 